\title{
UPAYA MENINGKATKAN HASIL BELAJAR SISWA \\ MELALUI PENERAPAN PENDEKATAN KETERAMPILAN PROSES \\ PADA KELAS VII SMP NEGERI 2 SUSUKAN \\ KABUPATEN BANJARNEGARA
}

\author{
Tri Lisnawati, Hariyanto, Santi Paramita \\ STABN Raden Wijaya Jawa Tengah
}

\begin{abstract}
In learning there are still teachers who have difficulty in managing learning activities. That is because learning activities only lead students to read and remember theories so as to make students less active and student learning outcomes low. This is the background of the author to conduct research, namely by applying the Process Skills Approach (PKP) in the learning process of Buddhist education to improve student learning outcomes. This research is a type of Classroom Action Research (CAR) conducted in class VII SMP N 2 Susukan Banjarnegara District, which amounted to 5 students. Several instruments are used to control learning activities, namely observation sheets, interview guidelines, and test questions. This study uses descriptive qualitative and quantitative descriptive data analysis techniques. The results showed the learning activities and student learning outcomes have increased after the learning process by applying the process skills approach. Through the application of PKP can improve student learning outcomes seen in test results, namely in Cycle I with the highest score of 75 and in Cycle II 98. In addition, student activity in learning activities also increased by $46.66 \%$ in Cycle I to 86, 66\% in Cycle II. The conclusion of this research is that the learning process by implementing PKP can improve student learning outcomes in class VII SMP Negeri 2 Susukan Banjarnegara Regency.

Keywords: Learning Outcomes, Process Skills Approach.
\end{abstract}

ABSTRAK

Pada pembelajaran masih ada guru yang mengalami kesulitan dalam mengelola kegiatan pembelajaran. Hal itu dikarenakan kegiatan pembelajaran hanya mengarahkan siswa untuk membaca dan mengingat teori saja sehingga membuat siswa menjadi kurang aktif dan hasil belajar siswa menjadi rendah. Hal tersebut yang melatarbelakangi penulis untuk melakukan penelitian, yaitu dengan menerapkan Pendekatan Keterampilan Proses (PKP) pada proses pembelajaran pendidikan agama Buddha untuk meningkatkan hasil belajar siswa. Penelitian ini merupakan jenis Penelitian Tindakan Kelas (PTK) yang dilakukan di kelas VII SMP N 2 Susukan Kabupaten Banjarnegara yang berjumlah 5 siswa. Digunakan beberapa instrumen untuk mengontrol kegiatan pembelajaran, yaitu lembar observasi, pedoman wawancara, dan soal tes. Penelitian ini menggunakan teknik analisis data deskriptif kualitatif dan deskriptif kuantitatif. Hasil penelitian menunjukkan kegiatan pembelajaran dan hasil belajar siswa sudah mengalami peningkatan setelah proses pembelajaran dengan menerapkan pendekatan keterampilan proses. Melalui penerapan PKP dapat meningkatkan hasil belajar siswa yang terlihat pada hasil tes, yaitu pada Siklus I dengan nilai tertinggi 75 dan pada Siklus II 98. Selain itu, keaktifan siswa dalam kegiatan pembelajaran juga mengalami peningkatan yaitu $46,66 \%$ pada Siklus I menjadi $86,66 \%$ pada Siklus II. Kesimpulan hasil penelitian ini adalah proses pembelajaran dengan menerapkan PKP dapat meningkatkan hasil belajar siswa pada kelas VII SMP Negeri 2 Susukan Kabupaten Banjarnegara.

Kata kunci: Hasil Belajar, pendekatan Keterampilan Proses (PKP). 


\section{PENDAHULUAN}

Pembelajaran merupakan kegiatan inti dari pendidikan yang bernilai edukatif. Nilai tersebut terbentuk dari interaksi antara guru dengan siswa dalam pembelajaran. Tujuan dari pembelajaran adalah tercapainya harapan siswa yang diartikan sebagai hasil belajar. Sedangkan untuk mencapainya, siswa perlu mengikuti proses pembelajaran dengan baik (Sumiati dan Asra, 2007: 10).

Berkaitan dengan proses pembelajaran, telah dijelaskan dalam Peraturan Pemerintah No. 32 Tahun 2013, tentang Standar Nasional Pendidikan. Dalam Standar Nasional Pendidikan terdapat Standar Proses, berkaitan dengan Standar Proses, proses pembelajaran pada satuan pendidikan harus diselenggarakan secara interaktif, inspiratif, menyenangkan, menantang, memotivasi siswa untuk berpartisipasi aktif, serta memberikan ruang yang cukup bagi prakarsa, kreativitas dan kemandirian sesuai dengan bakat minat dan perkembangan fisik serta psikologis siswa (Suparta, 2006: 164).

Pembelajaran yang baik akan terwujud apabila faktor-faktor yang mempengaruhi proses pembelajaran sudah dikondisikan dengan baik, seperti media pembelajaran, sumber dan bahan belajar, metode dan pendekatan pembelajaran yang sesuai, situasi belajar, keadaan siswa, serta keadaan guru. Berkaitan dengan kondisi guru dan siswa, keduanya harus mempunyai kesiapan, yaitu kesiapan guru untuk mengajar dan kesiapan siswa untuk belajar.

Cara mempersiapkan seorang siswa untuk belajar juga telah ditunjukkan oleh Sang Buddha, misalnya dengan memberi makan orang yang lapar sebelum Beliau menyampaikan khotbah-
Nya (Mukti, 2006: 315). Meskipun demikian, terkadang dalam proses pembelajaran siswa masih dihadapkan dengan berbagai masalah.

Siswa yang menghadapi kesulitan dalam mengikuti proses pembelajaran pendidikan agama Buddha terlihat lebih pasif dan cenderung kurang menanggapi materi yang disampaikan oleh guru. Sedangkan siswa yang tidak menghadapi kesulitan, terlihat lebih aktif, bersemangat, dan lebih fokus pada materi pembelajaran. Selain itu, siswa yang aktif mengikuti proses pembelajaran tidak hanya menerima saja, tetapi juga dapat mengelola, menggunakan, dan mengkomunikasikan hasil belajarnya. Dengan demikian proses pembelajaran menjadi lebih aktif.

Proses pembelajaran bertujuan untuk meningkatkan kemampuan kognitif, afektif, dan psikomotor siswa. Peningkatan tersebut dapat dilakukan melalui peningkatan kemampuan dan keterampilan siswa. Peningkatan kemampuan dan keterampilan pada siswa memerlukan adanya praktek langsung atau keterlibatan siswa. Guru juga harus menyadari bahwa untuk melibatkan siswa perlu adanya keaktifan dari siswa itu sendiri.

Keterlibatan siswa tidak hanya terbatas pada keterlibatan fisik saja, tetapi juga keterlibatan mental, emosional, dan kognitif siswa untuk pembentukan sikap, nilai, dan keterampilanketerampilan pada diri siswa. Siswa perlu aktif dan terlibat langsung dalam proses pembelajaran, karena pengalaman langsung akan lebih mudah dipahami oleh siswa dibandingkan dengan mengingat dan menghafal teori saja. Oleh karena itu, guru perlu menerapkan pendekatan pembelajaran yang dapat menciptakan keaktifan.

Pendekatan pembelajaran merupakan suatu upaya untuk meningkatkan keaktifan siswa dan keaktifan proses pembelajaran. Keaktifan tersebut 
terjadi pada berbagai kegiatan dan interaksi, baik interaksi antara guru dengan siswa maupun antar siswa itu sendiri. Pendekatan pembelajaran yang diterapkan harus disesuaikan dengan kemampuan siswa, materi, dan sarana prasarana sekolah. Dalam pendekatan pembelajaran, guru dapat menerapkan aspek keterampilan yang dapat mengaktifkan siswa dalam proses pembelajaran. Kemudian aspek keterampilan tersebut dituangkan dalam Rencana Pelaksanaan Pembelajaran (RPP) sebagai indikator pembelajaran.

Aspek keterampilan tersebut misalnya, keterampilan mengobservasi, mengklasifikasikan, mengkomunikasikan, mengukur, memprediksi, dan menyimpulkan hasil belajar. Dengan menyusun RPP sebelum dilaksanakan proses pembelajaran, maka akan mempermudah guru dalam mengelola proses pembelajaran. Pendekatan pembelajaran seperti demikian membuat peranan siswa akan lebih besar, karena siswa adalah subjek yang berinteraksi bukan hanya dengan guru tetapi juga dengan sumber belajar lainnya, seperti siswa lain, buku-buku, media dan lingkungan sekolah. Selain itu, siswa akan merasa senang dan dihargai oleh guru karena dapat berperan aktif dalam pembelajaran, tidak hanya mendengar cerita dari guru saja.

Namun pada pelaksanaannya, masih ada guru yang melaksanakan pembelajaran belum sepenuhnya mengacu pada perangkat pembelajaran. Guru tidak selalu membuat RPP sebelum mengajar. Guru hanya mengacu pada buku-buku pelajaran yang dipakai untuk mengajar saja, tanpa memperhatikan indikator yang harus dicapai oleh siswa pada tiap-tiap materi pembelajaran. Proses pembelajaran yang terjadi hanya berpusat pada guru, sedangkan siswa sebagai subjek yang hanya menerima materi yang diberikan oleh guru saja. Siswa menjadi kurang aktif dan proses pembelajaran juga menjadi kurang efektif. Akibatnya, materi yang diterima oleh siswa terbatas pada buku pelajaran dan tidak berkembang pengetahuannya. Sehingga, harapan guru tentang keberhasilan pembelajaran juga belum terwujud dalam tindakan nyata, seperti hasil belajar yang masih belum maksimal.

Hasil belajar yang belum maksimal menjadi masalah dan tanggung jawab bagi guru dan siswa itu sendiri. Bagi guru, guru harus lebih baik dalam mengelola proses pembelajaran. Sedangkan bagi siswa, siswa perlu meningkatkan keaktifannya dalam proses pembelajaran, karena hasil belajar tidak hanya dilihat dari nilai atau kemampuan kognitif saja, tetapi juga kemampuan afektif dan psikomotor.

Menurut Benjamin S. Bloom hasil belajar meliputi perubahan pada tiga ranah, yaitu ranah kognitif, misalnya dari belum atau tidak tahu menjadi tahu, ranah afektif, misalnya dari bersikap acuh tak acuh menjadi penuh perhatian pada pelajaran, dan ranah psikomotor, misalnya dari belum terampil bertanya menjadi terampil dalam hal bertanya (Bermawy, 2009: 57). Jadi, hasil belajar dapat dilihat dari ada atau tidaknya perubahan yang terjadi pada ketiga ranah tersebut setelah siswa mengikuti proses pembelajaran.

Hasil belajar penting bagi guru dan siswa, yaitu untuk mengetahui tingkat keberhasilan guru dalam mengajar dan tingkat keberhasilan siswa dalam menguasai materi yang telah diajarkan oleh guru. Sehingga proses pembelajaran dan hasil belajar sangatlah penting untuk diamati. Hasil belajar yang maksimal tergantung dari nilai dan keaktifan siswa dalam proses pembelajaran. Semakin baik proses pembelajaran dan keaktifan 
siswa, maka hasil belajar yang diperoleh akan maksimal sesuai dengan tujuan yang telah dirumuskan, dan sebaliknya apabila proses pembelajaran dan keaktifan siswa kurang, maka hasil belajar kurang maksimal (Asep Jihad, 2008: 20). Oleh karena itu, sebagai seorang guru harus benar-benar memperhatikan perangkat pembelajaran sebelum pembelajaran dilaksanakan.

Keterampilan dan kemampuan guru dalam mengelola proses pembelajaran dapat berpengaruh terhadap keberhasilan pembelajaran. Guru pada dasarnya mengetahui cara melaksanakan pembelajaran yang baik agar tujuan pembelajaran tercapai, namun guru belum dapat sepenuhnya mengaplikasikannya dalam proses pembelajaran. Hal tersebut peneliti temukan pada saat wawancara dengan guru mata pelajaran pendidikan agama Buddha SMP Negeri

2 Susukan Kabupaten Banjarnegara, yaitu Ibu Purwati.

Ibu Purwati adalah seorang guru wiyata bakti di beberapa sekolah, mulai dari SD, SMP, dan SMA. Meskipun beliau masih seorang guru wiyata bakti, akan tetapi beliau mempunyai semangat mengajar yang tinggi. Beliau adalah sosok guru agama Buddha yang peduli terhadap kebutuhan siswa akan pelajaran pendidikan agama Buddha di setiap sekolah. Terkait dengan proses pembelajaran pada kelas VII SMP Negeri 2 Susukan Kabupaten Banjarnegara, dari hasil wawancara tersebut diketahui bahwa keaktifan dan hasil belajar siswa dalam pendidikan agama Buddha masih rendah. Hal tersebut dikarenakan oleh beberapa faktor yaitu: guru tidak selalu membuat RPP, akibatnya proses pembelajaran tidak dapat terkelola dengan baik. Dalam proses pembelajaran, guru lebih menekankan siswa untuk membaca dan mengingat teori saja, sehingga siswa menjadi kurang aktif.

Hal lain yang peneliti temukan setelah wawancara dengan guru mata pelajaran pendidikan agama Buddha, yaitu ada beberapa siswa yang belum mendapat pelajaran pendidikan agama Buddha ketika berada di Sekolah Dasar. Sehingga pengetahuan siswa tentang agama Buddha masih sangat kurang. Hal itu terlihat pada saat peneliti melakukan observasi, siswa terlihat pasif dan cenderung diam hanya mendengarkan guru.

Pendekatan pembelajaran yang sesuai dengan suasana pembelajaran tersebut yaitu dengan penerapan Pendekatan Keterampilan Proses (PKP). PKP adalah pendekatan yang menekankan pada pengembangan keterampilanketerampilan dasar (basic skill) yaitu mulai dari mengobservasi atau mengamati untuk mengumpulkan informasi, mengklasifikasi, mengkomunikasikan, mengukur, memprediksi, dan menyimpulkan (Dimyati \& Mudjiono, 2010: 141-145). Karena pada dasarnya keterampilanketerampilan dasar sudah ada pada diri siswa, maka tugas guru adalah untuk mengaktifkan dan mengembangkan kembali keterampilanketerampilan dasar tersebut.

Berdasarkan keadaan di lapangan yang peneliti temukan, maka peneliti mengadakan penelitian pada siswa kelas VII SMP Negeri 2 Susukan Kabupaten Banjarnegara. Peneliti mengadakan penelitian dengan menerapkan pendekatan pembelajaran yang baru, yaitu PKP agar siswa dapat lebih aktif dalam pembelajaran dan hasil belajarnya menjadi lebih maksimal. Penelitian tersebut berjudul “ Upaya Meningkatkan Hasil Belajar Siswa Melalui Penerapan Pendekatan Keterampilan Proses Pada 
Kelas VII SMP Negeri 2 Susukan Kabupaten Banjarnegara".

\section{Rumusan Masalah}

Berdasarkan pada latar belakang masalah yang telah diuraikan, maka peneliti merumuskan masalah dalam penelitian yaitu apakah penerapan pendekatan keterampilan proses dapat meningkatkan hasil belajar siswa?

\section{Tinjauan Pustaka}

Hasil belajar menurut A.J. Romizowski adalah keluaran (outputs) yang berupa kinerja (performance) dari suatu sistem masukan informasi-informasi (input) (dalam Asep jihad dan Abdul Haris, 2008: 14). Hasil belajar sangat penting untuk diamati, karena dengan hasil belajar dapat diilihat tingkat perkembangan baik guru maupun siswa setelah proses pembelajaran. Hasil belajar menurut Djono R, Chosiyah, dan A. Syamsuri (2001: 37) merupakan hasil proses pembelajaran yang dapat dilihat dari dua sisi, yaitu:

a. Sisi siswa, hasil belajar merupakan tingkat perkembangan mental yang lebih baik dari sebelum proses pembelajaran dan terwujud dalam ranah kognitif, afektif, dan psikomotor.

b. Sisi guru, hasil belajar merupakan saat terselesaikannya bahan pelajaran yang terdapat dalam tujuan instruksional.

Hasil belajar tidak dapat dilihat hanya dari nilai saja, tetapi juga dari perubahan sikap dan keterampilan siswa setelah mengikuti proses pembelajaran. Menurut Bloom (dalam Djamarah, 2010: 106) hasil belajar mencakup peringkat dan tipe prestasi belajar, kecepatan belajar, dan hasil afektif atau yang biasa kita kenal dengan ranah kognitif, afektif, dan psikomotor. Selanjutnya
Bloom berpendapat bahwa hasil belajar dapat dikelompokkan ke dalam dua macam yaitu :

a. Pengetahuan yang meliputi empat kategori: pengetahuan tentang fakta, pengetahuan tentang prosedural, pengetahuan tentang konsep dan pengetahuan tentang prinsip.

b. Keterampilan yang meliputi empat kategori: keterampilan untuk berpikir (kognitif), keterampilan untuk bertindak (motorik), keterampilan bersikap dan keterampilan berinteraksi.

Telah dijelaskan pada sebelumnya bahwa hasil belajar tidak hanya berhubungan dengan intelektual siswa saja, tetapi juga sikap dan keterampilan siswa. Selain itu, dari segi agama juga dapat dilihat dari perubahan kecerdasan spiritualnya, untuk itu pendidikan agama Buddha perlu diberikan pada setiap jenjang pendidikan.

Pentingnya pendidikan agama Buddha bagi siswa yang beragama Buddha, sesuai dengan Cakkavati-Sihanada Sutta dalam buku Panduan Tipitaka Kitab Suci Agama Buddha yang berbunyi: Para Bhikkhu, jadilah pulau bagi diri kalian, jadilah pelindung bagi dirimu sendiri, jangan ada perlindungan lainnya. Jadikan Dhamma sebagai pulau bagi dirimu, jadikan Dhamma sebagai pelindungmu, jangan ada perlindungan lain" (Lanny Anggawati dan Wena Cintiawati, 2000: 63).

Menurut Andersen (dalam Harun Rasyid dan Mansur, 2007: 13) yang sependapat dengan Bloom bahwa karakteristik manusia meliputi cara yang tipikal dari berpikir, berbuat, dan perasaan. Tipikal berpikir berkaitan dengan ranah kognitif, tipikal perasaan berkaitan dengan ranah afektif dan tipikal berbuat berkaitan dengan ranah psikomotor. Rendahnya hasil belajar siswa merupakan masalah serius dalam dunia 
pendidikan, termasuk di Indonesia. Hal tersebut sesuai dengan pernyataan dari Siti Rahayu Haditono (dalam Djono R, Chosiyah, dan A. Syamsuri, 2001: 34) bahwa di Indonesia juga ditemukan banyak siswa yang memperoleh hasil belajar yang rendah. Hal tersebut dikarenakan faktor-faktor seperti:

a. Kurangnya fasilitas belajar di sekolah dan rumah diberbagai pelosok.

b. Siswa makin dihadapkan oleh berbagai pilihan dan mereka merasa ragu dan takut gagal.

c. Kurangnya dorongan mental dari orang tua karena orang tua tidak memahami apa yang dipelajari oleh anaknya di sekolah.

d. Keadaan gizi yang rendah, sehingga siswa tidak mampu belajar lebih baik, dan

e. Gabungan dari faktor-faktor tersebut memperngaruhi berbagai hambatan belajar (Siti Rahayu Haditono dalam Djono R, Chosiyah, dan A. Syamsuri, 2001: 34).

Menurut Muhibbin Syah (2010: 129) faktorfaktor yang mempengaruhi hasil belajar yaitu:

\section{a. Faktor Internal Siswa}

Faktor internal siswa yaitu keadaan atau kondisi jasmani dan rohani siswa. Faktor tersebut meliputi:

1) Aspek fisiologis

Kesehatan fisik sangat berpengaruh terhadap keberhasilan belajar siswa. Menurut Muhibbin Syah (2010: 130) kondisi organ tubuh yang lemah dapat menurunkan kualitas ranah cipta (kognitif) sehingga materi yang disampaikan pada pembelajaran kurang dapat dimengerti. Dalam pembelajaran guru harus memperhatikan kondisi pertumbuhan siswa agar pembelajaran dapat berhasil, karena anak yang perkembangan fisiknya baik maka mampu menunjukkan keterampilan motor yang baik pula (Sri Esti Wuryani Djiwandono, 2006: 71).

2) Aspek Psikologis

Faktor ini berpengaruh terhadap kuantitas dan kualitas hasil belajar siswa. Faktor psikologis meliputi:

a) Inteligensi Siswa

Salah satu faktor keberhasilan belajar siswa yaitu intelegensi. Menurut Muhibbin Syah (2010: 130) tingkat kecerdasan atau inteligensi (IQ) sangat menentukan tingkat keberhasilan siswa. Semakin tinggi kemampuan inteligensi siswa maka semakin besar peluangnya untuk meraih sukses. Ngalim Purwanto (2007: 103) juga sependapat dengan Syah bahwa selain kematangan, keberhasilan seseorang dalm mempelajari sesuatu juga ditentukan oleh taraf kecerdasan

b) Sikap siswa

Sikap adalah kemampuan menerima atau menolak suatu obyek, dalam pembelajaran obyek tersebut berupa kesempatan belajar. Menurut Dimyati dan Mudjiono (2010: 239) akibat dari penerimaan, penolakan, atau pengabaian terhadap kesempatan belajar akan berpengaruh pada hasil belajar.

c) Minat dan Bakat Siswa

Minat (intersest) berarti kecenderungan atau keinginan yang besar terhadap sesuatu hal. Sedangkan bakat (aptitude) adalah kemampuan potensial yang dimiliki seseorang untuk mencapai keberhasilan pada masa yang akan datang (Reber dalam Muhibbin Syah, 2010: 133). Sehubungan dengan hasil belajar, minat dan bakat dapat mempengaruhi tinggi rendahnya 
hasil belajar siswa yang akan berpengaruh juga terhadap prestasi belajar siswa.

d) Motivasi

$$
\text { Kurangnya motivasi akan }
$$
menyebabkan kurangnya semangat siswa dalam proses pembelajaran yang akan berdampak pada hasil belajar siswa. Menurut Dimyati dan Mudjiono (2010: 94) motivasi belajar yang semakin meningkat, maka tujuan belajarnya juga akan tercapai.

\section{b. Faktor Eksternal}

Faktor eksternal siswa yaitu kondisi lingkungan di sekitar siswa. Faktor tersebut meliputi:

1) Lingkungan Sosial

Faktor lingkungan sosial baik di sekolah maupun lingkungan keluarga akan sangat berpengaruh terhadap aktvitas belajar siswa, seperti kurikulum, guru, masyarakat, tetangga, dan teman sepermainan. Menurut Dimyati dan Mudjiono (2009: 253) lingkungan sosial memberi pengaruh terhadap siswa berupa pengaruh kejiwaan, suasana belajar yang kondusif ataupun tidak, dapat memperkuat atau memperlemah konsentrasi belajar siswa dan tentunya berdampak pada hasil belajar siswa.

Faktor-faktor lingkungan perlu dipertimbangkan untuk melakukan kegiatan pembelajaran. Kegiatan pembelajaran hampir sama dengan kegiatan meditasi. Dalam melakukan meditasi juga harus memilih kondisi lingkungan yang sesuai dengan watak dan subjek yang melakukan meditasi. Misalnya seperti yang terdapat dalam Kitab Suci Dhammapada Bab VII Syair 99, yaitu melakukan meditasi di hutan untuk mereka yang melatih diri dengan menyingkir dari keduniawian (Surya Widya, 2008: 39).

2) Lingkungan Non Sosial

Lingkungan ini dapat berupa gedung sekolah, jarak rumah ke sekolah, sarana dan prasarana belajar, keadaan cuaca, serta waktu belajar. Berdasarkan hasil penelitian oleh Dunn et al (dalam Muhibbin Syah, 2010: 136) berkaitan dengan waktu belajar, maka hasil belajar yang maksimal bukan hanya tergantung pada waktu secara mutlak, tetapi bergantung pada pilihan waktu yang cocok dengan kesiapan siswa dalam belajar.

\section{c. Faktor Pendekatan Belajar}

Faktor pendekatan belajar yaitu jenis upaya belajar siswa yang meliputi strategi dan metode yang digunakan siswa untuk melakukan kegiatan mempelajari materi-materi pelajaran. Menurut Muhibbin Syah (2010: 123) melalui pendekatan pembelajaran yang efektif dan eifisien, hasil belajar siswa yang mempunyai kemampuan ratarata dapat mendapatkan hasil belajar yang lebih maksimal

Faktor pendekatan belajar yaitu jenis upaya belajar siswa yang meliputi strategi dan metode yang digunakan siswa untuk melakukan kegiatan mempelajari materi-materi pelajaran. Menurut Muhibbin Syah (2010: 123) melalui pendekatan pembelajaran yang efektif dan eifisien, hasil belajar siswa yang mempunyai kemampuan ratarata dapat mendapatkan hasil belajar yang lebih maksimal. Faktor pendekatan belajar sangat mempengaruhi hasil belajar siswa, sehingga semakin mendalam cara belajar siswa semakin baik hasilnya. 


\section{Pendekatan Keterampilan Proses (PKP)}

PKP yaitu pendekatan yang bertujuan untuk mengembangkan keterampilan-keterampilan intelektual, sosial dan fisik yang pada dasarnya bersumber dari kemampuan-kemampuan yang sudah ada dalam diri siswa (Dimyati dan Mudjiono, 2009: 138). Pengembangan keterampilan tersebut meliputi pengembangan keterampilan-keterampilan intelektual, sosial, dan fisik yang pada dasarnya bersumber dari kemampuan-kemampuan yang sudah ada dalam diri siswa (Dimyati dan Mudjiono, 2010: 138).

Sang Buddha juga pernah memberikan perumpamaan kepada para Bhikkhu yang berbunyi:

"Ada sebuah kereta di atas tanah yang rata, berada di persimpangan jalan, ditarik oleh empat ekor kuda yang bagus, siap menunggu dengan cambuk, sehingga kusir yang mahir juga sebagai ahli penjinak dapat naik dan memegang tali pengendali agar dapat mengendara kereta ke manapun yang kusir inginkan, begitu pula saya (Sang Buddha) tidak perlu terus-terusan mengajar bhikkhu-bhikkhu itu. Saya (Sang Buddha) hanya membangkitkan perhatian mereka" (Cornelis Wowor, 1993: 89).

Belajar pada dasarnya adalah proses yang terjadi dalam diri siswa yang diaktifkan oleh siswa itu sendiri. Dalam pendekatan keterampilan proses, guru bertugas untuk memberikan kemudahan kepada peserta didik dalam menciptakan lingkungan yang kondusif agar semua siswa dapat berkembang secara optimal. Jadi, peran guru PKP juga sama seperti Sang Buddha ketika mengajar para murid-Nya. Sedangkan keberhasilan siswa dalam pembelajaran tergantung dari usaha siswa itu sendiri, semakin giat siswa belajar maka pengetahuan siswa akan semakin bertambah.

Beberapa hal yang menjadi dasar dari penerapan PKP menrut Dimyati \& Mudjiono (2010: 137-139), yaitu:

a. Percepatan perubahan Ilmu Pengetahuan dan Teknolog

b. Pengalaman intelektual, emosional, dan fisik dibutuhkan agar didapatkan hasil belajar yang optimal

c. Penanaman sikap dan nilai sebagai bentuk penghargaan siswa terhadap suatu hasil melalui suatu proses.

Setiap metode maupun pendekatan pembelajaran mempunyai kelebihan tersendiri. Guru harus memilih pendekatan pembelajaran yang sesuai dengan karkteristik siswa dan karakteristik mata pelajaran. Keunggulan dari penerapan PKP (dalam Dimyati dan Mudjiono, 2010: 137) pada proses pembelajaran adalah:

a. Siswa terlibat langsung dengan objek nyata sehingga dapat mempermudah pemahaman siswa terhadap materi pelajaran.

b. Siswa menemukan sendiri konsep-konsep yang dipelajari.

c. Melatih siswa untuk berpikir lebih kritis.

d. Melatih siswa untuk bertanya dan terlibat lebih aktif dalam pembelajaran.

e. Mendorong siswa untuk menemukan konsepkonsep baru.

f. Memberi kesempatan kepada siswa untuk belajar menggunakan metode ilmiah.

\section{Jenis-Jenis Keterampilan dalam Pendekatan}

\section{Keterampilan Proses}

Funk (dalam Dimyati dan Mudjiono, 2010: 140) mengungkapkan bahwa dalam pendekatan keterampilan proses terdiri dari keterampilan- 
keterampilan dasar (basic skill) dan keterampilanketerampilan terintegrasi (integrated skill). Keterampilan-keterampilan proses dikelompokkan oleh Funk, menjadi enam keterampilan proses dasar, yaitu:
a. Mengamati
b. Mengklasifikasikan
c. Mengomunikasikan
d. Mengukur/membandingkan
e. Memprediksi
f. Menyimpulkan

\section{METODE PENELITIAN}

Penelitian yang berjudul Upaya Meningkatkan Hasil Belajar Siswa melalui Penerapan Pendekatan Keterampilan Proses (PKP) pada Kelas VII SMP Negeri 2 Susukan Kabupaten Banjarnegara menggunakan metode Penelitian Tindakan Kelas (PTK) atau Classroom Action Research model kolaboratif dengan desain penelitian siklus. Penelitian ini dilaksanakan dalam dua siklus yang meliputi tahapan-tahapan: perencanaan, pelaksanaan, observasi, dan refleksi pada tiap siklusnya. Secara skematis, siklus kegiatan tindakan yang dilakukan dapat dilihat pada gambar di bawah ini:

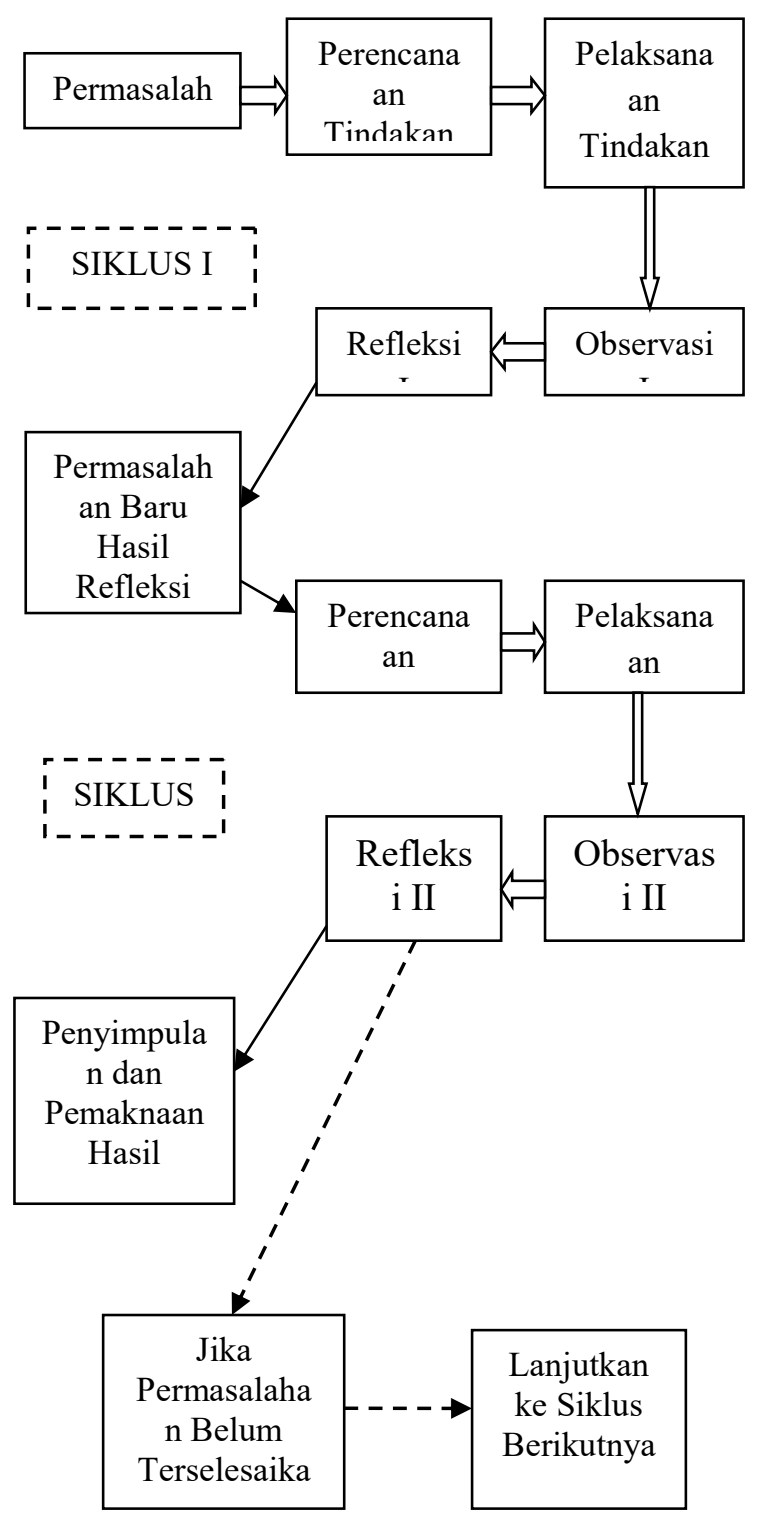

Gambar 1.

Desain PTK

\section{Lokasi, Waktu, dan Subjek Penelitian}

Penelitian ini dilaksanakan oleh peneliti di SMP Negeri 2 Susukan Kecamatan Susukan Kabupaten Banjarnegara pada bulan FebrusariMei. Subjek penelitian ini adalah siswa kelas VII tahun ajaran 2013/2014.

\section{Teknik Pengumpulan dan Analisis Data}

Teknik pengumpulan data dalam penelitian ini adalah melalui observasi, tes, dan wawancara. Observasi dilakukan pada saat proses pembelajaran pendidikan agama Buddha dengan fokus pengamatan pelaksanaan penerapan PKP 
dengan instrumen yang digunakan berupa lembar observasi. Tes dilakukan sebelum dan sesudah pelaksanaan tindakan. Sedangkan wawancara dilakukan kepada guru dan siswa setelah tindakan selesai dilakukan.

Penelitian ini menggunakan teknik analisis data deskriptif kualitatif dan deskriptif kuantitatif. Analisis deskriptif kualitatif yaitu analisis data yang berupa informasi yang berbentuk kalimat, sedangkan analisis deskriptif kuantitatif adalah analisis data yang berupa nilai hasil belajar siswa.

\section{PEMBAHASAN}

Proses pemberian tindakan pada penelitian ini dilaksanakan dalam 2 siklus, yaitu iklus I dan siklus II. Masing-masing siklus terdiri dari 4 tahap, yaitu perencanaan, pelaksanaan, observasi, dan refleksi. Namun, pada perencanaan untuk siklus II disusun dengan memperhatikan hasil refleksi pada siklus I, sehingga ada suatu perbaikan tindakan dari siklus I. Adapun hasil dari penelitian ini adalah:

\section{Hasil Tes}

\begin{tabular}{|l|l|c|c|c|}
\hline \multirow{2}{*}{ No. } & \multirow{2}{*}{ Nama } & \multicolumn{2}{|c|}{ Siklus I } & $\begin{array}{c}\text { Siklus } \\
\text { II }\end{array}$ \\
\cline { 3 - 5 } & & $\begin{array}{c}\text { Pre } \\
\text { Test }\end{array}$ & $\begin{array}{c}\text { Post } \\
\text { Test }\end{array}$ & $\begin{array}{c}\text { Post } \\
\text { Test }\end{array}$ \\
\hline 1. & Siswa 1 & 40 & 60 & 85 \\
\hline 2. & Siswa 2 & 50 & 70 & 88 \\
\hline 3. & Siswa 3 & 50 & 75 & 90 \\
\hline 4. & Siswa 4 & 70 & 75 & 95 \\
\hline 5. & Siswa 5 & 70 & 75 & 98 \\
\hline
\end{tabular}

Sumber : Diolah Peneliti

Pada saat penelitian dilaksanakan, Kriteria Ketuntasan Minimum (KKM) yang telah ditetapkan oleh sekolah tersebut adalah 75. Hasil pre test menunjukkan bahwa belum ada siswa yang berhasil mencapai KKM, setelah dilaksanakan post test pada siklus I, kemudian ada 3 siswa yang telah mencapai KKM dengan nilai 75. Sedangkan pada post test siklus II, nilai seluruh siswa sudah mencapai KKM semua, dengan nilai terendah 85 , dan nlai tertinggi 98 .

\section{Hasil Observasi Proses pembelajaran}

\begin{tabular}{|c|c|c|c|}
\hline Siklus & $\begin{array}{c}\text { Skor } \\
\text { Maksimal }\end{array}$ & $\begin{array}{c}\text { Jumlah } \\
\text { Skor } \\
\text { Jawaban }\end{array}$ & Persentase \\
\hline Siklus I & 75 & 51 & $60 \%$ \\
\hline Siklus II & 75 & 70 & $93,33 \%$ \\
\hline
\end{tabular}

Sumber : Diolah Peneliti

Persentase hasil observasi terhadap proses pembelajaran pada siklus I sebesar $60 \%$ termasuk dalam kriteria baik,dan mengalami peningkatan $33,33 \%$ menjadi $93,33 \%$ termasuk dalam kriteria sangat baik.

\section{Hasil Observasi Guru}

\begin{tabular}{|l|l|l|l|}
\hline \multicolumn{1}{|c|}{ Siklus } & $\begin{array}{c}\text { Skor } \\
\text { Maksimal }\end{array}$ & $\begin{array}{c}\text { Jumlah } \\
\text { Skor } \\
\text { Jawaban }\end{array}$ & Persentase \\
\hline Siklus I & 39 & 20 & $51 \%$ \\
\hline Siklus II & 39 & 36 & $92,30 \%$ \\
\hline
\end{tabular}

Sumber : Diolah Peneliti

Persentase hasil observasi terhadap guru pada siklus I masih kurang, yaitu sebesar 51\%, sedangkan pada siklus II meningkat menjadi $92,30 \%$.

\section{Hasil Observasi Siswa Siklus I}

\begin{tabular}{|l|l|l|l|}
\hline Siklus & $\begin{array}{c}\text { Skor } \\
\text { Maksimal }\end{array}$ & $\begin{array}{c}\text { Jumlah } \\
\text { Skor } \\
\text { Jawaban }\end{array}$ & Persentase \\
\hline Siklus I & 39 & 20 & $51 \%$ \\
\hline Siklus II & 39 & 36 & $92,30 \%$ \\
\hline
\end{tabular}

Sumber : Diolah Peneliti

Persentase hasil observasi terhadap siswa pada siklus I masih kurang, yaitu sebesar 51\%. Hal tersebut menunjukkan masih perlu ada perbaikan 
pada siklus berikutnya. Setelah dilaksanakan perbaikan pada siklus II, persentasi hasil observasi terhadap siswa menjadi lebih baik yaitu sebesar $92,30 \%$.

\section{Hasil Observasi Keaktifan Siswa I}

\begin{tabular}{|c|c|c|c|}
\hline Siklus & $\begin{array}{c}\text { Skor } \\
\text { Maksimal }\end{array}$ & $\begin{array}{c}\text { Jumlah } \\
\text { Skor } \\
\text { Jawaban }\end{array}$ & Persentase \\
\hline Siklus I & 15 & 7 & $47 \%$ \\
\hline Siklus II & 15 & 14 & $93,33 \%$ \\
\hline
\end{tabular}

Sumber : Diolah Peneliti

Persentase hasil observasi terhadap keaktifan siswa pada siklus I sebesar $47 \%$ termasuk dalam kriteria baik,dan mengalami peningkatan menjadi 93,33\% termasuk dalam kriteria sangat baik.

\section{Hasil Observasi Penguasaan PKP Siklus I}

\begin{tabular}{|c|c|c|c|}
\hline Siswa & $\begin{array}{c}\text { Skor } \\
\text { Maksimal }\end{array}$ & $\begin{array}{c}\text { Jumlah } \\
\text { Skor } \\
\text { Jawaban }\end{array}$ & Persentase \\
\hline Siswa 1 & \multirow{5}{*}{27} & 12 & $44 \%$ \\
\hline Siswa 2 & & 13 & $48,14 \%$ \\
\hline Siswa 3 & & 13 & $48,14 \%$ \\
\hline Siswa 4 & & 13 & $48,14 \%$ \\
\hline Siswa 5 & & 13 & $48,14 \%$ \\
\hline \multicolumn{2}{|c|}{ Rerata } & 12,8 & $47,70 \%$ \\
\hline
\end{tabular}

Sumber : Diolah Peneliti

\section{Hasil Observasi Penguasaan PKP Siklus II}

\begin{tabular}{|c|l|l|l|}
\hline \multirow{2}{*}{ Siswa } & $\begin{array}{c}\text { Skor } \\
\text { Maksimal }\end{array}$ & $\begin{array}{c}\text { Jumlah } \\
\text { Skor } \\
\text { Jawaban }\end{array}$ & Persentase \\
\hline \multirow{2}{*}{ Siswa 1 } & \multirow{4}{*}{27} & 22 & $81,48 \%$ \\
\hline \multirow{2}{*}{ Siswa 2 } & 24 & $88,88 \%$ \\
\hline \multirow{2}{*}{ Siswa 3 } & 24 & $88,88 \%$ \\
\hline Siswa 4 & 26 & $96,29 \%$ \\
\hline Siswa 5 & 26 & $96,29 \%$ \\
\hline \multicolumn{2}{|c|}{ Rerata } & 24,4 & $90,37 \%$ \\
\hline
\end{tabular}

Sumber : Diolah Peneliti

Hasil persentase observasi terhadap penguasaan keterampilan proses pada siswa pada Asosiasi Dosen \& Unit Penelitian dan Pengabdian Masyarakat siklus I masih sangat kurang, dengan rata-rata keberhasilan siswa dalam menguasai keterampilan proses sebesar $47,70 \%$, sedangkan pada siklsu II sudah mengalami peningkatan dengan persentase sebesar $90,37 \%$.

Pembahasan hasil penelitian didasarkan pada hasil pengamatan proses pembelajaran berlangsung serta hasil refleksi. Dari hasil refleksi Siklus I diperoleh data sebagai berikut:

a. Masih perlu adanya perbaikan dan peningkatan keterampilan dan kemampuan guru dalam mengelola pembelajaran, karena pada Siklus I guru masih kurang mampu untuk mengembangkan keterampilan proses pada siswa.

b. Keaktifan dan keberanian siswa dalam kegiatan pembelajaran masih perlu didorong agar lebih aktif dan lebih berani bertanya serta berpendapat, karena persentase keaktifan siswa pada Siklus I hanya $46,66 \%$.

c. Hasil tes terakhir pada Siklus I dari 5 siswa hanya 3 siswa yang sudah memenuhi KKM dengan nilai 75 .

Dari hasil refleksi dan pembahasan pada Siklus I dijadikan dasar untuk perbaikan pada Siklus II.

\section{Siklus II}

Hasil pembahasan yang didasarkan pada refleksi Siklus II diperoleh hasil sebagai berikut:

1) Ada peningkatan yang baik pada aktivitas siswa dalam kegiatan pembelajaran dengan persentase pada Siklus I 46,66\% meningkat menjadi 86,66\% dalam kategori sangat baik.

2) Kemampuan dan keterampilan guru dalam mengelola kegiatan pembelajaran sudah menjadi lebih baik dengan presentasi pada 
Siklus I $66,66 \%$ menjadi $94,87 \%$ pada Siklus II.

3) Dari hasil tes pada Siklus I hanya 3 Siswa yang memenuhi KKM, sedangkan pada Siklus II nilai dari seluruh siswa sudah memenuhi KKM dengan nilai rata-rata 91,2.

Dari hasil refleksi proses tindakan dan pembahasan Siklus I dan Siklus II, serta berdasarkan hasil tes akhir pada Siklus I dan Siklus II telah terjadi peningkatan pada tiaptiap jenis observasi. Peningkatan tersebut dapat dilihat pada grafik dibawah ini.

\section{KESIMPULAN}

Dari keseluruhan kegiatan penelitian yang telah dilaksanakan oleh peneliti pada siswa kelas VII di SMP Negeri 2 Susukan Kabupaten Banjarnegara, dapat disimpulkan bahwa proses pembelajaran dengan menerapkan Pendekatan Keterampilan Proses (PKP) dapat meningkatkan hasil belajar siswa.

\section{Saran}

1. Bagi guru.

$>$ PKP perlu diterapkan dalam kegiatan pembelajaran untuk meningkatkan keaktifan siswa dan keaktifan proses pembelajaran.

$>$ PKP perlu diterapkan dalam kegiatan pem,belajaran, khususnya pendidikan agama Buddha untuk meningkatkan hasil belajar siswa.

$>$ Dalam penerapan PKP guru perlu memperhatikan kesesuaian antara materi pelajaran dengan jenis keterampilan proses, sehingga keterampilan proses dapat dikuasai oleh siswa.
2. Bagi Civitas Akademika STAB N Raden Wijaya.

$>$ Dapat menciptakan alumni STAB N Raden Wijaya, khususnya pada jurusan Dharmacarya sebagai tenaga pendidik yang profesional.

> Adanya hasil penelitian ini diharapkan dapat dijadikan sebagai acuan untuk melakukan penelitian lanjutan.

3. Bagi siswa.

$>$ Siswa diharapakan lebih aktif pada proses pembelajaran.

> Siswa diharapkan mampu menerapkan ilmu pengetahuan yang telah diperoleh dalam kehidupan sehari-hari.

\section{DAFTAR PUSTAKA}

Aan Hasanah. (2012). Pengembangan Profesi Guru. Bandung: CV. Pustaka Setia.

Asep Jihad \& Abdul Haris.(2008).Evaluasi Pembelajaran. Yogyakarta: Multi Pressindo.

Bermawy Munthe. (2009). Desain Pembelajaran.Yogyakarta: PT. PustakaInsanMadani.

Cornelis Wowor. (1993). Materi Pokok Kitab Suci Sutta Pitaka II. Jakarta: Direktorat Jenderal Bimbingan Masyarakat Hindu dan Buddha dan Universitas Terbuka.

Dimyati \& Mudjiono.(1991/1992). Strategi Belajar Mengajar.DepDikBud Direktorat Jenderal Pendidikan Tinggi Proyek Pembinaan Tenaga Kependidikan. (2010).Belaj ar dan Pembelajaran. Jakarta: Rineka Cipta.

Djono R, Chosiyah, \& A. Syamsuri. (2001). Bimbingan dan Konseling Belajar. Surakarta: Universitas Sebelas Maret.

Harun Rasyid, dan Mansur. (2007). Penilaian Hasil Belajar. Jakarta: CV. Wacana Prima.

Ikwanu Sofa. (2011). http://library.ikippgrismg.ac.id/docfiles/full text/e6e31123d22d25fe.pdf diambil pada tanggal 24 Maret 2114 upaya meningkatkan hasil belajar siswa dengan menggunakan pendekatan keterampilan proses. Diakses pada jam 10:03 WIB. 
Khrisnanda Wijaya Mukti. (2006). Wacana Buddha Dhamma: Jakarta Yayasan Dharma Pembangunan.

Khairil Anwar Notodiputro, (2013). http://www.pendidikan-

diy.go.id/file/mendiknas/kurikulum/-2013kompetensi-dasar-smp-ver-3-3-2013.pdf diambil pada tanggal 24 Maret 2014 kurikulum 2013. Diakses pada jam 10:26 WIB.

Lanny Anggawati \& Wena Cintiawati. (2000). Panduan Tipitaka Kitab Suci Agama Buddha.Klaten: Vihara Bodhivamsa. . (2006). Majjhima Nikaya 3 Kitab

Suci Agama Buddha. Klaten: Vihara Bodhivamsa.

Masnur Muslich. (2013). Melaksanakan PTK itu Mudah. Jakarta: PT. Bumi Aksara.

Mohammad Asrori. (2007). Psikologi Pembelajaran.Bandung: CV. Wacana Prima.

Muhibbin Syah. (2010). Psikologi Pendidikan dengan Pendekatan Baru. Bandung: PT. Remaja Rosdakarya.

Ngalim Purwanto. (2007). Psikologi Pendidikan. Bandung: PT. Remaja Rosdakarya.

Rusman. (2011). Model-Model Pembelajaran, Mengembangkan Profesionalisme Guru. Jakarta: Rajawali Pers.

Sri Esti Wuryani Djiwandono. (2006). Psikologi Pendidikan. Jakarta: PT. Grasindo.

Surya Widya. (2008). Dhammapada. Jakarta: Yayasan Abdi Dhamma Indonesia.

Suharsimi Arikunto. (2013). Manajemen Penelitian. Jakarta: PT. Rineka Cipta.

Sumiati \& Asra. (2007). MetodePembelajaran. Jakarta: CV. Wacana Prima.

Suparta. (2006). Undang-Undang dan PeraturanPemerintah RI tentang Pendidikan. Jakarta: Direktorat Jenderal Pendidikan Islam Departemen Agama RI.

Syaiful Bahri Djamarah \& Aswan Zain. (2006). StrategiBelajarMengajar. Jakarta: RinekaCipta.

Suyati.

http://sumsel1.kemenag.go.id/file/dokumen /PendekatanKeterampilanProses.pdf

diambil pada tanggal 27 januari 2014 pengajaran dengan pendekatan keterampilan proses. Diakses pada jam 15.44 WIB.

Trianto. (2013). Model Pembelajaran Terpadu. Jakarta: Bumi Aksara.

Yeni

Emilia, http://repository.unej.ac.id/bitstream/handle 1123456789/11838/Yeni\%20Emilia 1.pdf diambil pada tanggal 24 Maret 2014

Asosiasi Dosen \& Unit Penelitian dan Pengabdian Masyarakat kurikulum 2013. Diakses pada jam 10:30 WIB. 